
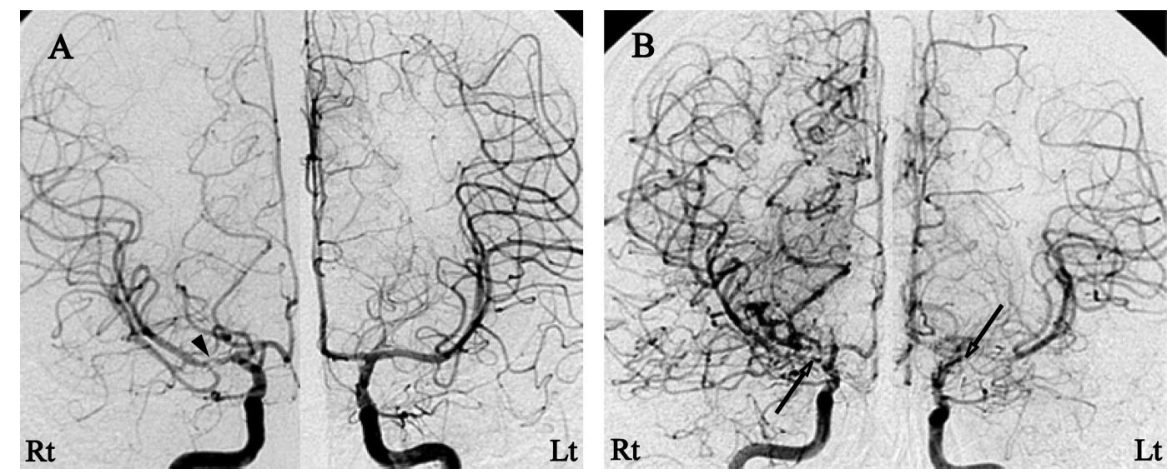

Figure. Angiography was performed twice, with an interval of 4 years and 8 months apart. (A) The initial angiography shows isolated stenosis of the right middle cerebral artery (arrowhead). (B) The follow-up angiography demonstrates typical features of moyamoya disease, including severe stenosis of the bilateral ICA (arrows) and basal collateral networks.

\section{Progression of isolated middle cerebral artery stenosis into moyamoya disease}

H.-Y. Choi, MD; J.E. Lee, MD; Y.H. Jung, MD; H.J. Cho, MD; D.J. Kim, MD; and J.H. Heo, MD, PhD, Seoul, Korea

The etiology of isolated middle cerebral artery (MCA) stenosis in young patients and that of moyamoya disease remain unclear. ${ }^{1}$ A 25-year-old woman with chronic headache underwent brain

\section{See also page 932}

Supported by a grant from the Korea Health 21 R\&D Project, Ministry of Health \& Welfare, Republic of Korea (A060171).

Disclosure: The authors report no conflicts of interest.

Address correspondence and reprint requests to Dr. Ji Hoe Heo, Department of Neurology, Yonsei University College of Medicine, 134 Shinchon-dong, Seodaemoon-ku, 120-752, Seoul, Korea; e-mail: jhheo@yumc.yonsei.ac.kr
MRI and cerebral angiography, which showed isolated MCA stenosis (figure, A). Physical and neurologic examinations were normal. She had no risk factors for atherosclerosis or stroke. Findings of the follow-up angiography, which was taken due to transient left arm weakness, were consistent with those of moyamoya disease (figure, B). ${ }^{2}$ Isolated MCA stenosis in a young patient with no other medical conditions may be an initial feature of moyamoya disease.

1. Becker VU, Eckert B, Thie A. Isolated symptomatic stenosis of the middle cerebral artery in younger adults. A clinical and ultrasonic follow-up study of eight patients. Eur Neurol 1996;36:65-70.

2. Fukui M. Guidelines for the diagnosis and treatment of spontaneous occlusion of the circle of Willis ("moyamoya" disease). Research Committee on Spontaneous Occlusion of the Circle of Willis (Moyamoya Disease) of the Ministry of Health and Welfare, Japan. Clin Neurol Neurosurg 1997;99(suppl 2):S238-240. 


\section{Neurology}

\section{Progression of isolated middle cerebral artery stenosis into moyamoya disease H.-Y Choi, J. E. Lee, Y. H. Jung, et al. \\ Neurology 2007;68;954 \\ DOI 10.1212/01.wnl.0000244412.18039.03}

\section{This information is current as of March 19, 2007}

Updated Information \&

Services

Supplementary Material

References

Subspecialty Collections

Permissions \& Licensing

Reprints including high resolution figures, can be found at: http://n.neurology.org/content/68/12/954.full

Supplementary material can be found at: http://n.neurology.org/content/suppl/2007/11/08/68.12.954.DC1

This article cites 1 articles, 0 of which you can access for free at: http://n.neurology.org/content/68/12/954.full\#ref-list-1

This article, along with others on similar topics, appears in the following collection(s):

\section{All Cerebrovascular disease/Stroke}

http://n.neurology.org/cgi/collection/all_cerebrovascular_disease_strok e

Infarction

http://n.neurology.org/cgi/collection/infarction

MRI

http://n.neurology.org/cgi/collection/mri

Information about reproducing this article in parts (figures,tables) or in its entirety can be found online at:

http://www.neurology.org/about/about_the_journal\#permissions

Information about ordering reprints can be found online:

http://n.neurology.org/subscribers/advertise

Neurology ${ }^{\circledR}$ is the official journal of the American Academy of Neurology. Published continuously since 1951, it is now a weekly with 48 issues per year. Copyright . All rights reserved. Print ISSN: 0028-3878. Online ISSN: 1526-632X.

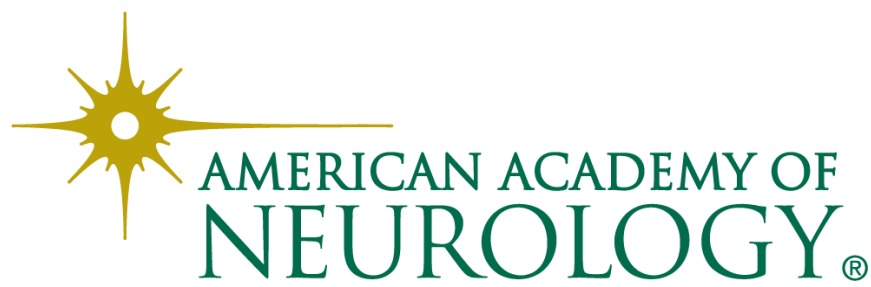

